\title{
Effects of Different Fat Sources on Fermentative Characteristics and Microbial Efficiency in the Rumen, and Nutrients Digestibility of Dairy Cows
}

\author{
N. J. Choi*, W. J. Maeng**, H. J. Kim**, H. G. Lee*** and J. K. Ha*** \\ Institute of Grassland and Environmental Research, Aberystwyth SY23 3EB, UK*, \\ Kon-Kuk University, Seoul, Korea**, Seoul National University, Seoul, Korea***
지방첨가원에 따른 젓소의 반추위 발효성상 미생물 합성 효율 및 영양소 소화율 영향 연구 최낙진* . 맹원재** . 김현진** . 이홍구*** . 하종규***
IGER 연구소, 영국*, 건국대학교 축산대학**, 서울대학교 농업생명과학대학***

$$
\text { 요 약 }
$$

사료 지방의 종류에 따른 반추위 내 발효성상, 미생물 합성 효율 및 영양소 소화율을 조사하기 위하여 반 추위와 십이지장에 누관이 설치된 4 마리의 홀스타인 젖소를 $4 \times 4$ 라틴 방각법 대사실험을 수행하였다. 공 시축들은 조사료 $60 \%$ 및 농후사료 $40 \%$ 비율의 완전혼합사료 형태로 급여하였다. 농후사료 내 지방원으로써 Megalac(MEG), 포름알데히드 처리 아마 종실(LIN), 어유와 포름알데히드 처리 아마종실 혼합(MIX; 50:50, oil basis), 그리고 농후사료 내 지방을 첨가하지 않고 아마유를 십이지장에 하루 $500 \mathrm{~g}$ 주입한 것(OIL)을 포 함하여 총 4 개의 처리구를 두었다. 반추위 $\mathrm{pH}$ 는 $\mathrm{OIL}$ 처리구에서 가장 낮았으나 $(\mathrm{P}<0.05)$, Ammonia $\mathrm{N}$ 농도 는 처리구들간 통계적 유의차가 없었다. Total VFA, acetate, propionate, iso-butyrate 및 iso-valerate 농도 또한 처리구들간 통계적 유의차이가 없었다. 반면에 butyrate와 valerate는 OIL 처리구에서 가장 높았고, MEG 처리 구에서 가장 낮았다(각각 $\mathrm{P}<0.05, \mathrm{P}<0.01$ ). A : P ratio 역시 OIL 처리구에서 가장 높은 반면에 MEG 처리구 에서 가장 낮았다(P<0.05). $\mathrm{DM}, \mathrm{OM}, \mathrm{NDF}$ 및 $\mathrm{ADF}$ 섭취량은 $\mathrm{OIL}$ 처리구에서 가장 낮았다(P<0.01). 그러나, 십이지장으로의 영양소들의 flow, 반추위와 전장 소화율은 처리구들간에 통계적 유의차이가 없었다. 질소 $(\mathrm{N})$ 섭취량은 $\mathrm{OIL}$ 처리구에서 가장 낮았다 $(\mathrm{P}<0.01)$. 십이지장으로의 total $\mathrm{N}$, nonammonia $\mathrm{N}$ 및 microbial $\mathrm{N}$ flow는 처리구들간 통계적 유의차이가 없었다. 그리고, 미생물합성효율, ammonia $\mathrm{N}$ 및 total $\mathrm{N}$ 의 반추위 및 전장 소화율 또한 처리구들간에 통계적 유의차이가 없었다. 따라서, 본 실험결과는 사료 내 $6 \%$ 정도의 지방 원료 첨가는 형태와 종류에 상관없이 반추위 발효성상, 미생물 합성 효율, 반추위 및 전장 내 영양소 이용 효율을 감소 시키지 않음을 나타내고 있다.

(Key words : Dietary Fat, Fermentation, Microbial Efficiency, Nutrient Digestibility)

\section{INTRODUCTION}

Fats and oils have been used to increase the dietary energy density for lactating dairy cows. However, dietary fat supplements are known to cause negative modification to fermentation and nutrient digestion in the rumen. Reductions have been demonstrated in fibre and organic matter digestion, methanogenesis, ammonia concentrations and acetate:propionate value(Devendra and Lewis, 1974; Palmquist and Jenkins, 1980). Therefore, various methods such as formaldehyde-treated emulsions of fat in proteins(Scott et al., 1971), calcium soaps(Jenkins and Palmquist, 1982), heat treatment(Tice et al., 1994), fatty acyl amides (Fotouhi and Jenkins, 1992), the crystalline hydrogenated fat(Elliott et al., 1994) and feeding whole oilseeds(Scollan et al., 2001) have been developed

Corresponding author : Professor J. K. Ha, School of Agricultural Biotechnology Seoul National University Seoul, 151-742, Tel : 02-880-4809, Fax : 02-875-8710, E-mail : jongha@snu.ac.kr 
for protecting fat sources from rumen metabolism, which offers the possibility that fat sources fed in such a form may interfere less with rumen metabolism.

Generally, oilseeds contain a higher proportion of unsaturated fatty acids than saturated fatty acids with $\mathrm{C} 18: 2 \mathrm{n}-6$ as the main component in most oilseeds, and C18:3 n-3 in linseed. In addition, fish oil is also an excellent source of $n-3$ polyunsaturated fatty acids(Sargent, 1996). The n-3 polyunsaturated fatty acids have been associated with positive effects on human health for a long time. Therefore, there is growing interest in increasing levels of n-3 polyunsaturated fatty acids in milk and meat because of benefits for human health. However, this interest is only focused on human health regardless of metabolic disorder of animals. It has been demonstrated that unsaturated fatty acids are more likely to alter microbial fermentation due to their greater effect on bacterial growth compared with saturated fatty acids(Maczulak et al., 1981; Jenkins, 1993).

The present study had relatively unsaturated dietary fat sources such as formaldehyde treated linseed, a mixture of formaldehyde treated linseed and fish oil, and duodenal linseed oil infusion, and relatively saturated dietary fat source such as megalac. A duodenal infusion of linseed oil was used to avoid completely dietary fat effects in the rumen. Therefore, the objective of the present study was to investigate effects of different dietary fat sources on rumen metabolism, nutrient digestibilities, and protection of fat sources in relation to rumen metabolism.

\section{П MATERIALS AND METHODS}

\section{Animals and Diets}

Four Holstein cows(initial live weight $670 \pm$ $7 \mathrm{~kg}$ ) were equipped with a rumen cannula and a simple ' $\mathrm{T}$ '-piece cannula(i.d. 20mm) in the proximal duodenum(Beever et al., 1978). Animals were housed in individual pens, and transferred to metabolism crates for each measurement period. The building was well ventilated and continuously illuminated and animals had free access to fresh water and mineral blocks. Silage(Table 1) was prepared from a single sward of perennial ryegrass without wilting, using a precision chop forage harvester(Alois Pottinger MBH Mex VIPU457, Grieskirchen, Germany) set to a theoretical chop length of $5 \mathrm{~cm}$. All cows were fed for ad libitum intake(10\% refusals) twice a day(08:00 and 16:00 h) a total mixed diet containing about $60 \%$ silage and $40 \%$ concentrate(DM basis). The four concentrates were formulated to contian 1) Megalac (MEG; Volac Ltd., Roston, Hertfordshire, UK), 2) formaldehyde-treated whole linseed(LIN), 3) a mixture(50:50, oil base) of fish oil and formaldehyde-treated whole linseed(MIX), or 4) no fat in the concentrate but with $500 \mathrm{~g}$ of linseed oil being infused daily into the duodenum at a constant rate over $23 \mathrm{~h}(\mathrm{OIL})$. All concentrates were in pelleted form and concentrate plus oil consumption were calculated to result in similar $\mathrm{CP}, \mathrm{ME}$, and oil intakes as a percentage of total DMI. A commercial salt of fatty acids(MEG) was used in the control $\operatorname{diet(MEG)~to~make~all~diets~iso-~energetic~and~}$ iso-oil. Concentration of formaldehyde in whole linseed reached $4 \%$ on a protein basis, which meets the minimum recommendation of $2 \%$ made by Scott et al.(1971). Treatment of linseed was carried out by adding $300 \mathrm{~g}$ of formalin per $\mathrm{kg}$ of whole linseeds to create $\mathrm{pH}$ reversible methylene bridges within the seed. Following treatment, the linseed was held for $5 \mathrm{~d}$ in curing vessels to allow methyl linkages to form. The protected linseed was bagged and stored at ambient temperature after the curing phase. A duodenal infusion of linseed oil was used for on treatment (OIL) in order to avoid completely dietary fat effects in the rumen. The fatty acid composition of concentrates differed among concentreates(data not shown), reflecting our formulation objectives. The concentrations of saturated fatty acids, particularly C16:0, were higher for 
Table 1. Formulation and chemical composition of the experimental diets.

\begin{tabular}{lccccc}
\hline & Silage & MEG & LIN & MIX & OIL \\
\hline \hline g/kg fresh & & & & & \\
Barley & & 542 & 544 & 546 & 584 \\
Mol. Sugarbeet & & 204 & 205 & 205 & 220 \\
Molasses & & 75 & 76 & 76 & 81 \\
Soya bean meal & & 86 & 0 & 49 & 94 \\
Megalac & 72 & 0 & 0 & 0 \\
Fish oil ${ }^{2)}$ & & 0 & 0 & 26 & 0 \\
Linseed & & 0 & 154 & 77 & 0 \\
Premix ${ }^{3)}$ & & 21 & 21 & 21 & 21 \\
\hline Chemical composition(g/kg DM) & & & & & \\
DM & 291 & 977.9 & 976.3 & 966.7 & 976.7 \\
pH & 3.67 & - & - & - & - \\
Total-N & 32.3 & 235.3 & 225.8 & 235.0 & 243.3 \\
Ammoina N & 2.14 & - & - & - & - \\
OM & 889 & 932 & 948 & 947 & 945 \\
NDF & 429 & 217.3 & 232.6 & 221.9 & 229.0 \\
ADF & 252 & 77.3 & 84.8 & 80.1 & 78.3 \\
Acetic acid & 14.26 & - & - & - & - \\
Ether Extract & 41.9 & 61.4 & 52.0 & 53.6 & 4.92 \\
Energy, Mcal/kg of DM & - & 4.33 & 4.37 & 4.44 & 4.15 \\
\hline
\end{tabular}

${ }^{1)}$ Volac Ltd., Roston, Hertfordshire, UK

${ }^{2)}$ South American herring(I.Spencer an Co., Ltd., Fleetwood, Lancashire, UK)

${ }^{3)}$ Premix contained 400,000IU of vitamin A/kg, 40,000IU of vitamin $\mathrm{D}_{3} / \mathrm{kg}, 20,000 \mathrm{IU}$ of vitamine $\mathrm{E} / \mathrm{kg}, 20,000 \mathrm{IU}$ of -tocopherol $/ \mathrm{kg}, 27 \% \mathrm{Ca}, 4.1 \% \mathrm{P}, 2500 \mathrm{mg} / \mathrm{kg}$ of $\mathrm{Mn}, 2500 \mathrm{mg} / \mathrm{kg}$ of $\mathrm{Zn}, 1500 \mathrm{mg} / \mathrm{kg}$ of $\mathrm{Cu}, 760 \mathrm{mg} / \mathrm{kg}$ of $\mathrm{Fe}$, $99 \mathrm{mg} / \mathrm{kg}$ of I, $40 \mathrm{mg} / \mathrm{kg}$ of Co, and $18 \mathrm{mg} / \mathrm{kg}$ of Se.

MEG, and C18:3 concentrations were higher for LIN and OIL. Fish oil(in diet MIX) was the only sources of C20:5 and C22: 6 .

\section{Experimental procedures}

The experiment was conducted as a $4 \times 4$ Latin square design. Each experimental period lasted 21d, with a $14 \mathrm{~d}$ adaptation period to the diets, followed by a $7 \mathrm{~d}$ measurement period. Silage was offered at $110 \%$ of the previous allocation at $09: 00 \mathrm{~h}$ and concentrates in two equal feeds at $09: 00$ and 16:00 h. Refusals were removed daily at $08: 30 \mathrm{~h}$ and recorded. Concentrates feed levels were adjusted weekly, based on silage consumption of the previous weeks silage consumption. Feces were collected utilizing the externally applied urine separators and techniques described in detail by Aston et al.(1998).

Digesta flow at the duodenum was estimated using dual-phase marker system with ytterbium acetate(YbAc) and chromium ethylene diamine tetra-acetic acid(CrEDTA) as the particulate and liquid markers, respectively(Faichney, 1975). On d 10, samples of duodenal digesta were taken to assess background levels of digesta markers. YbAc(50mg Yb/kg DM intake) and CrEDTA (1750mg/day) were then infused via separate lines intraruminally at a rate of $20 \mathrm{ml} / \mathrm{h}$, for 10 days. On d 17 and 18, samples of duodenal digesta were collected over a $48 \mathrm{~h}$ period using an automatic sampling apparatus(Evans et al., 1981) removing approximately $5 \%$ of the digesta passing the cannula. On d 21, rumen fluid samples were taken before the morning feed and $0.5,1,2,3,4,5,6$, and $9.5 \mathrm{~h}$ after the feed was offered. On completion of rumen sampling diets changeovers were commenced. 


\section{Sample preparation and analysis}

Separate samples of fresh silage and concentrates were taken daily during the measurement periods. Sub-samples were either stored frozen or freezedried, ground and retained for chemical analysis. Oven $\operatorname{DM}\left(100^{\circ} \mathrm{C}\right)$ was determined 3 times per week to allow offered feed levels to be adjusted. Accumulated samples of daily duodenal digesta were thoroughly mixed and a sub-sample was freezedried representing whole digesta, a portion of which was centrifuged at $2000 \mathrm{rev} / \mathrm{min}$ for $10 \mathrm{~min}$ to provide the centrifuged solid digesta. These were subsequently freeze-dried, ground and retained frozen for analysis. Rumen $\mathrm{pH}$ was measured immediately after the samples were taken and then acidified with $2.5 \mathrm{M}$ sulphuric acid and stored at $-20^{\circ} \mathrm{C}$.

The DM content of grass silage was determined by toluene distillation(TDM; Dewar and McDonald, 1961) and oven DM was measured at $100^{\circ} \mathrm{C}$ for 24 h. OM was analysed by ashing at $550^{\circ} \mathrm{C}$ for $6 \mathrm{~h}$ in a muffle furnace. Volatile components of silage (aqueous extract: $20 \mathrm{~g}$ silage in $100 \mathrm{ml}$ water) and rumen liquor were determined by GC(Fussell and McCalley, 1987). Ammonia was assessed enzymatically using glutamate dehydrogenase on a discrete analyser(FP-901M Chemistry Analyzer, Labsystems Oy, Helsinki, Finland; Test kit No. 66-50, Sigma-Aldrich Co. Ltd., Poole, Dorset). Ammonia content of digesta was determined after extraction in water and analysed immediately. Total $\mathrm{N}$ was determined by the micro-Kjeldahl technique using 'Kjeltec equipment'(Perstorp Analytical Ltd., Maidenhead, Berkshire). Neutral detergent fibre was determined as described by Van Soest et al.(1991) and acid detergent fibre was analysed according to Van Soest and Wine(1967) using the Tecator Fibretec System equipment(Tecator Ltd., Thornbury, Bristol). Acid hydrolysis ether extracts (AHEE) was measured using 'Soxtec' equipment(Perstorp Analytical Ltd., Maidenhead, Berkshire) incorporating the additional acid hydrolysis and extraction step described in Ministry of Agriculture, Fisheries \&
Food(1992). Chromium and ytterbium concentrations of digesta and infusate solutions were determined by atomic absorption spectrophotometry (Siddons et al. 1985).

\section{Calculations and statistical analysis}

Digesta flows and apparent digestibility of nutrients in the rumen was calculated after mathematical reconstitution of true digesta as described by Faichney(1975). Apparent fatty acid digestibility in the total tract was calculated from the difference between intake and fecal output. The hourly estimates of rumen $\mathrm{pH}$, ammonia $\mathrm{N}$ and VFA concentrations were analysed using a repeated measures analysis of variance(Genstat 5; Lawes Agricultural Trust, 1995). The model fitted was:

$$
\mathrm{Y}_{\mathrm{ijk}}=\mu+\mathrm{A}_{j}+\mathrm{P}_{i}+\mathrm{D}_{k}+\mathrm{e}_{i j k}
$$

where $\mu$ is the overall mean, $A_{j}$ is the effect of animal $(j=1-4), P_{i}$ is the effect of $\operatorname{period}(i=1-$ 4), $D_{k}$ is the effect of $\operatorname{diet}(k=1-4)$ and $e_{i j k}$ is the residual error term.

\section{RESULTS AND DISCUSSION}

The chemical composition of the four concentrates(Table 1) was very similar, with no difference in $\mathrm{DM}, \mathrm{OM}, \mathrm{CP}, \mathrm{NDF}, \mathrm{ADF}$ or ether extract concentrations. Rumrn $\mathrm{pH}$, ammonia $\mathrm{N}$ and VFA concentrations, averaged across sampling times, are shown in Table 2. It could be expected that rumen $\mathrm{pH}$ is lower in OIL treatment compared with others because duodenal infusion of linseed oil avoided dietary fat effects in the rumen. As expected, the rumen $\mathrm{pH}$ was lowest in OIL among the treatments $(\mathrm{P}<0.05)$. The reason for this may be perhaps due to higher amount of dietary starch or physical stress with duodenal oil infusion in addition to above mentioned reason. The rumen $\mathrm{pH}$ was low in OIL treatment, it seems that continuous duodenal infusion of linseed oil have no adverse effect on the cow's health. This is because rumen 
Table 2. Effect of different fat sources on rumen fermentation

\begin{tabular}{lrrrrrc}
\hline & MEG & LIN & MIX & OIL & SED $^{1)}$ & P $^{2)}$ \\
\hline \hline $\mathrm{pH}$ & 6.34 & 6.29 & 6.40 & 6.06 & 0.079 & $*$ \\
\hline Ammonia N(mg/l) & 110.7 & 108.2 & 131.6 & 115.5 & 24.73 & NS \\
\hline VFA(mM) & & & & & & \\
Total & 88.96 & 92.46 & 91.44 & 113.73 & 5.697 & NS \\
Acetic acid(A) & 48.51 & 50.92 & 50.71 & 62.39 & 4.894 & NS \\
Propionate acid(P) & 21.04 & 21.99 & 21.52 & 24.85 & 2.199 & NS \\
Iso-Butyric acid & 0.99 & 1.01 & 0.90 & 1.08 & 0.083 & NS \\
n-Butyric acid & 14.99 & 15.09 & 15.00 & 20.86 & 1.858 & $*$ \\
Iso-Valeric acid & 1.65 & 1.58 & 1.39 & 2.02 & 0.227 & NS \\
n-Valeric acid & 1.78 & 1.87 & 1.92 & 2.53 & 0.120 & $*$ \\
A:P ratio & 2.34 & 2.37 & 2.37 & 2.56 & 0.060 & $*$ \\
\hline
\end{tabular}

1) $\mathrm{SED}=$ standard error deviation.

2) NS, not significant $(\mathrm{P}>0.05) ; * \mathrm{P}<0.05 ; * * \mathrm{P}<0.01$

$\mathrm{pH}$ was higher than 6.0. Stewart(1977) reported that digestion of fiber decreases as rumen $\mathrm{pH}$ declines, especially when it is decreased below 6.0. Ammonia $\mathrm{N}$ concentration was not significantly different among the treatments reflecting dietary nitrogen contents were similar in the diets. Although total VFA, acetate, propionate, iso-butyrate and isovalerate concentrations tended to be higher in OIL, the differences were not significant. This could be explained that the rapid and extensive ruminal fermentation of starch may result in high concentrations of VFA, which lowers rumen $\mathrm{pH}$. The concentrations of butyrate and valerate were highest in OIL and lowest in MEG(P $<0.05$ and $\mathrm{P}$ $<0.01$, respectively). In addition, $\mathrm{A}: \mathrm{P}$ ratio was also highest in OIL and lowest in MEG(P $<0.05)$. Palmquist and Jenkins(1980) observed that A:P ratio in the rumen was reduced by fat supplementation. Generally, characteristic of ruminal fermentation in cows have not been altered by supplementation of as much as 6\% of dietary fat (Schauff and Clark, 1989; Klusmeyer et al., 1991; Drackley and Elliott, 1993). As shown in Table 1, the proportion of dietary ether extract was between 5 and $6 \%$ in treatments. Therefore, rumen parameter showed no adverse effect on the rumen metabolism regardless of treatments.

Intake, duodenal flow, ruminal and total tract digestibility of nutrients are shown in Table 3. As expected, intake of nutrients(DM, OM, NDF, ADF and total nitrogen) was lowest in OIL among the treatments $(\mathrm{P}<0.01)$. Other researchers have also reported a decrease in DM intake of dietary source when cows are infused with unsaturated fat (Bremmer et al., 1998). In addition, Cant et al. (1997) observed that a decreased 10\% in DM intake was noted when the fish oil diets were fed because the diets had a fish odour which may have reduced cow's palatability. However, the present results indicated that fish oil had no negative effect on DM intake. Unlike to the present study, this is because silage and concentrate were fed separately so the reduction in ad libitum silage intake by addition of fish oil to the concentrate suggests a more general effect on feed consumption in the work of Cant et al.(1997). While all nutrients flow to the duodenum, and digestion in the rumen and total tract were not significantly different among the treatments. Ruminal DM and OM digestibilities were on average $28 \%$ and 38\%, respectively. These values are similar to results of Kalscheur et al.(1997) who observed DM and OM digestibilities in the rumen were $29 \%$ and $36 \%$, respectively when diets contained $60 \%$ of forage regardless supplemental buffer. While, in their work, low DM and OM digestibilities in the rumen were observed in $25 \%$ of forage in the diets(Kalscheur et al., 1997). Therefore, this suggest that forage proportion in the 
Table 3. Effects of different fat sources on DM, OM, NDF and ADF intake and digestibility

\begin{tabular}{|c|c|c|c|c|c|c|}
\hline & MEG & LIN & MIX & OIL & $\mathrm{SED}^{1)}$ & $\mathrm{P}^{2)}$ \\
\hline \multicolumn{7}{|l|}{ Dry matter } \\
\hline Intake, kg/d & 17.5 & 17.2 & 17.1 & 15.6 & 0.33 & $* *$ \\
\hline Duodenal flow, kg/d & 13.0 & 11.91 & 12.1 & 11.8 & 1.16 & NS \\
\hline Rumen digestibility, \% & 27.2 & 30.7 & 29.6 & 24.2 & 7.60 & NS \\
\hline Total tract digestibility, \% & 77.3 & 76.9 & 80.0 & 78.0 & 1.01 & NS \\
\hline \multicolumn{7}{|l|}{ Organic matter } \\
\hline Intake, kg/d & 16.2 & 15.9 & 15.7 & 14.3 & 0.30 & $* *$ \\
\hline Duodenal flow, kg/d & 10.1 & 9.6 & 9.5 & 9.4 & 0.92 & NS \\
\hline Rumen digestibility, \% & 37.9 & 39.3 & 39.4 & 33.9 & 6.09 & NS \\
\hline Total tract digestibility, \% & 78.7 & 78.3 & 81.2 & 79.6 & 1.11 & NS \\
\hline \multicolumn{7}{|l|}{ Neutral detergent fibre } \\
\hline Intake, kg/d & 6.2 & 6.2 & 5.9 & 5.50 & 0.13 & $* *$ \\
\hline Duodenal flow, kg/d & 3.1 & 3.2 & 3.1 & 3.3 & 0.21 & NS \\
\hline Rumen digestibility, \% & 49.4 & 48.2 & 47.6 & 40.7 & 4.72 & NS \\
\hline Total tract digestibility, \% & 75.9 & 76.0 & 77.8 & 77.2 & 0.91 & NS \\
\hline \multicolumn{7}{|l|}{ Acid detergent fibre } \\
\hline Intake, kg/d & 3.3 & 3.2 & 3.1 & 2.9 & 0.05 & $* *$ \\
\hline Duodenal flow, kg/d & 2.0 & 2.1 & 2.0 & 1.9 & 0.11 & NS \\
\hline Rumen digestibility, \% & 40.0 & 35.6 & 36.2 & 34.4 & 3.97 & NS \\
\hline Total tract digestibility, \% & 75.9 & 75.8 & 76.9 & 77.0 & 0.87 & NS \\
\hline
\end{tabular}

1), 2) As Table 2.

diet could affect nutrient digestibility in the rumen. DM The duodenal infusion of linseed oil had no effect on DM digestibility, in agreement with previous studies involving abomasal infusions of fat(Christensen et al., 1994; Drackley et al., 1992; Oldick et al., 1997).

Effect of dietary fat sources on $\mathrm{N}$ metabolism is shown in Table 4. Intake of $\mathrm{N}$ was highest in MEG, but lowest in OIL treatment $(\mathrm{P}<0.01)$. Duodenal flow of total $\mathrm{N}$, nonammonia $\mathrm{N}$ and microbial $\mathrm{N}$, and microbial synthesis were not significantly affected by different dietary fat sources. The present result was similar to the previous result of Ueda et al.(2003) that duodenal flow of nonammonia $\mathrm{N}$ and bacterial $\mathrm{N}$, and efficiency of bacterial $\mathrm{N}$ synthesis were not affected by feeding linseed oil. However, unlike present results, they found that duodenal flow of nonammonia $\mathrm{N}$ and bacterial $\mathrm{N}$ were greater with concentrate-rich diets compared with foragerich diets due to decreased ruminal protozoal numbers(Ueda et al., 2003). Ammonia $\mathrm{N}$ and total $\mathrm{N}$ digestibility were not affected by different dietary fat sources. Therefore, it appears that $\mathrm{N}$ metabolism and microbial $\mathrm{N}$ efficiency are affected by not dietary fat source but by other factors such as forage: concentrate ratio. Negative ruminal $\mathrm{N}$ digestibilities in treatments indicated that microbial de novo $\mathrm{N}$ synthesis occurred in the rumen.

In conclusion, dietary fat supplementation in the diet with less than $6 \%$ for dairy cows had no negative effects on rumen ecosystem and nutrients digestibility in the rumen and total tract regardless of dietary fat type.

\section{ABSTRACT}

Four Holstein cows were used in a $4 \times 4$ Latin square experiment to study effects of fat sources on rumen metabolism and digestibility of nutrients. All cows were fed a total mixed diets containing 60\% silage and $40 \%$ concentrate. The four concentrates were formulated to contain either Megalac(MEG), formaldehyde-treated whole linseed(LIN), a mixture ( $50: 50$, oil basis) of fish oil and formaldehyde- 
Table 4. Effects of different dietary fat sources on digestion of $\mathrm{N}$ and microbial flow to the small intestine of cows

\begin{tabular}{|c|c|c|c|c|c|c|}
\hline & MEG & LIN & MIX & OIL & SED $^{1)}$ & $\mathrm{P}^{2)}$ \\
\hline Intake, g/d & $5 \overline{10}$ & $4 \overline{91}$ & $4 \overline{91}$ & $4 \overline{53}$ & 10.09 & *** \\
\hline \multicolumn{7}{|l|}{ Duodenal flow, g/d } \\
\hline Total N & 544 & 531 & 530 & 499 & 41.0 & NS \\
\hline Ammonia $\mathrm{N}$ & 25 & 22 & 15 & 20 & 1.1 & \\
\hline Nonammoina $\mathrm{N}$ & 518 & 513 & 513 & 410 & 10.40 & NS \\
\hline Microbial N & 215 & 174 & 167 & 168 & 43.2 & NS \\
\hline $\begin{array}{l}\text { Microbial synthesis, } \\
\mathrm{g} \text { of } \mathrm{N} / \mathrm{kg} \text { of } \mathrm{OMTD}^{3)}\end{array}$ & 35.59 & 28.67 & 28.66 & 31.40 & 8.4818 & NS \\
\hline $\begin{array}{l}\text { Ammonia } \mathrm{N} \text { digestibility } \\
\text { in the rumen, } \%\end{array}$ & 89.26 & 91.62 & 91.37 & 90.23 & 3.1469 & NS \\
\hline $\begin{array}{l}\text { Total } N \text { digestibility } \\
\text { in the rumen }\end{array}$ & -5.5 & -8.1 & -7.7 & -10.9 & 9.91 & NS \\
\hline $\begin{array}{l}\text { Total } N \text { digestibility } \\
\text { in the total tract, \% }\end{array}$ & 70.1 & 67.2 & 63.5 & 71.0 & 5.63 & NS \\
\hline
\end{tabular}

${ }^{1),}{ }^{2)}$ As Table 2.
3) $\mathrm{OM}$ truly digested in the rumen.

treated whole linseed(MIX), or no fat source in the concentrate but $500 \mathrm{~g}$ per day of linseed oil being infused into the duodenum (OIL). The rumen $\mathrm{pH}$ was lowest in OIL among the treatments $(\mathrm{P}<0.05)$, but ammonia $\mathrm{N}$ concentration in the rumen was not significantly different among the treatments. The differences of total VFA, acetate, propionate, iso-butyrate and iso-valerate concentrations were not significant among the treatments. While, butyrate and valerate were highest in OIL and lowest in $\operatorname{MEG}(\mathrm{P}<0.05$ and $\mathrm{P}<0.01$, respectively). In addition, A:P ratio was also highest in OIL and lowest in $\operatorname{MEG}(P<0.05)$. As expected, intake of nutrients(DM, OM, NDF and $\mathrm{ADF}$ ) was lowest in OIL among the treatments $(\mathrm{P}<0.01)$. However, all nutrients flow to the duodenum, and digestion in the rumen and total tract were not significantly different among the treatments. Intake of $\mathrm{N}$ was highest in MEG, but lowest in OIL treatment $(\mathrm{P}<0.01)$. Duodenal flow of total $\mathrm{N}$, nonammonia $\mathrm{N}$ and microbial $\mathrm{N}$ was not significantly different across the treatments. In addition, microbial synthesis and ammonia $\mathrm{N}$ and total $\mathrm{N}$ digestibility were not affected by different dietary fat sources. The present results show that fermentative characteristic and microbial efficiency in the rumen, and nutrients digestibility in the rumen and total tract were not depressed by supplementation of as much as $6 \%$ dietary fat sources.

\section{$\mathrm{V}$ REFERENCES}

1. Aston, K., Fisher, W. J., McAllan, A. B., Dhanoa, M. S. and Dewhurst, R. J. 1998. Supplementation of grass silage-based diets with small quantities of concentrates: Strategies for allocating concentrate crude protein. Anim. Sci. 67:17-26.

2. Beever, D. E., Kellaway, R. C., Thomson, D. J., MacRae, J. C., Evans, C. C. and Wallace, A. S. 1978. A comparison of two non-radioactive digesta marker systems for the measurement of nutrient flow at the proximal duodenum of calves. J. Agric. Sci, Camb. 90:157-163.

3. Bremmer, D. R., Ruppert, L. D., Clark, J. H. and Drackley, J. K. 1998. Effect of chain length and unsaturation of fatty acid mixtures infused into the abomasums of lactating dairy cows. J. Dariy Sci. 81: 176-188.

4. Cant, J. P., Fredeen, A. H., Maclntyre, T., Gunn, J. and Crowe, N. 1997. Effect of fish oil and monensin on milk composition in dairy cows. Can. J. Anim. Sci. 77:125-131.

5. Christensen, R. A., Drackely, J. K., LaCount, D. W. and Clark, J. H. 1994. Infusion of four long- chain fatty acid mixtures into the abomasums of lactating dairy cows. J. Dairy Sci. 77:1052-1069.

6. Devendra, C. and Lewis, D. 1974. The interaction between dietary lipids and fiber in the sheep. Anim. 
Prod. 19:67-76.

7. Dewar, W. A. and McDonald, P. 1961. Determination of dry matter in silage by distillation with toluene. J. Sci. Food Agric. 12:790-795.

8. Drackley, J. K., Klusmeyer, T. H., Trusk, A. M. and Clark, J. H. 1992. Infusion of long-chain fatty acids varying in saturation and chain length into the abomasums of lactating dairy cows. J. Dairy Sci. 75:1517-1526

9. Drackley, J. K. and Elliot, J. P. 1993. Milk composition, ruminanl characteristics, and nutrient utilization in dairy cows fed partially hydrogenated tallow. J. Dairy Sci. 76:183.

10. Elliott, J. P., Overton, T. R. and Drackley, J. K. 1994. Digestibility and effects of three forms of mostly saturated fatty acids. J. Dairy Sci. 77:789- 798.

11. Evans, R. T., Evans, K. V. and Beever, D. E. 1981. Portable equipment for the automatic sampling of duodenal contents from housed of grazing cattle. Laboratory Pract. 30:997.

12. Faichney, G. J. 1975. The use of markers to partition digestion within in the gastro-intestinal tract of ruminants. In: Digestion and Metabolism in the Ruminant. pp. 277-291.[I. W. McDonald and A. C. I. Warner, editors]. The University of New England Publishing Unit, Armidale, NSW.

13. Fotouhi, N. and Jenkins, T. C. 1992. Resistance of fatty acyl amides to degradation and hydrogenation by ruminal microorganisms. J. Dairy Sci. 75:1527- 1532.

14. Fussell, R. J. and McCalley, D. V. 1987. Determination of volatile fatty acids $\left(\mathrm{C}_{2}-\mathrm{C}_{5}\right)$ and lactic acid in silages by gas chromatography. Analyst 112:1213-1216.

15. Jenkins, T. C. and Palmquist, D. L. 1982. Effect of added fat and calcium on in vitro formation of insoluble fatty acid soaps and cell wall digestibility. J. Anim. Sci. 55:957-963.

16. Jenkins, T. C. 1993. Lipid metabolism in the rumen. J. Dairy Sci. 76:3851-3863.

17. Kalscheur, K. F., Teter, B. B., Piperova, L. S. and Erdman, R. A. 1997. Effect of dietary forage concentration and buffer addition on duodenal flow of trans-C18:1 fatty acids and milk fat production in dairy cows. J. Dairy Sci. 80:2104-2114.

18. Klusmeyer, T. H., Lynch, G. L., Clark, J. H. and Nelson, D. R. 1991. Effects of calcium salts of fatty acids and protein source on ruminal fermentation and nutrient flow to the duodenum of cows. J. Dairy Sci. 74:2206-2219.

19. Lawes Agricultural Trust. 1995. GENSTAT V mark 2.2. Rothamsted Experimental Station, Harpenden, UK.

20. Maczulak, A. E., Dehority, B. A. and Palmquist, D. L. 1981. Effects of long-chain fatty acids on growth of rumen bacteria. Appl. Environ. Microbiol. 42:856-862.
21. Ministry of Agriculture, Fisheries \& Food, 1992. Prediction of energy value of compound feeding stuffs for farm animals. Summary of recommendations of a working party sponsored by the Ministry of Agriculture, Fisheries and Food.

22. Oldick, B. S., Staples, C. R., Thatcher, W. W. and Gyawu, P. 1997. Abomasal infusion of glucose and fat: Effect on digestion, production, and ovarian and uterine functions of cows. J. Dairy Sci. 80:1315-1328.

23. Palmquist, D. L. and Jenkins, T. C. 1980. Fat in lactation rations: a review. J. Dairy Sci. 64:1-14.

24. Sargent, J. R. 1996. Fish oils and human diet. In: Fats in the Diet of Animals and Man.(Ed. D. I. Givens) Proceedings of ADAS Conference, Birmingham. p.13.

25. Schauff, D. J. and Clark, J. H. 1989. Effects of prilled fatty acids and calcium salts of fatty acids on rumen fermentation, nutrient digestibilites, milk production, and composition. J. Dairy Sci. 72:917.

26. Scollan, N. D., Dhanoa, M. S., Choi, N, J., Maeng, W. J., Enser, M. and Wood, J. D. 2001. Digestion of long chain fatty acids from different feed sources and their effect on the rumen function of steers. J. Agric. Sci., Camb. 136:345-355.

27. Scott, T. W., Cook, L. J. and Mills, S. C. 1971. Protection of dietary polyunsaturated fatty acids against microbial hydrogenation in ruminants. J. Am. Oil Chem. Soc. 48: 359-364.

28. Siddons, R. C., Paradine, J., Beever, D. E. and Cornell, P. R. E. 1985. Ytterbium acetate as a particulate phase digesta flow marker. Br. J. Nutr. 54:509-519.

29. Stewart, C. S. 1977. Factors affecting the cellulolytic activity of rumen contents. Appl. Environ. Microbiol. 33:497-502.

30. Tice, E. M., Eastridge, M. L. and Firkins, J. L. 1994. Raw soybeans and roasted soybeans of different particle size. 2. Fatty acid utilization by lactating cows. J. Dairy Sci. 77:166-180.

31. Ueda, K., Ferlay, A., Chabrot, J., Loor, J. J., Chilliard, Y. and Doreau, M. 2003. Effect of linseed oil supplementation on ruminal digestion in dairy cows fed diets with different forage: concentrate ratios. J. Dairy Sci. 86:3999-4007.

32. Van Soest, P. J. and Wine, R. H. 1967. Use of detergents in the analysis of farmers feeds. IV. Determination of Plant Cell Wall Constituents. J. Assoc. Official Analy. Chem. 50:50-55.

33. Van Soest, P. J., Robertson, J. B. and Lewis, B. A. 1991. Methods for dietary fiber, neutral detergent fiber, and non-starch polysaccharides in relation to animal nutrition. J. Dairy Sci. 74:3583-3597.

(접수일자 : 2004. 1. 5. / 채택일자 : 2004. 5. 24.) 